\title{
Occult hepatitis B virus infection among hemodialysis patients
}

\author{
Rahil Nahid Samiei, ${ }^{1,2}$ Somayeh Shokri, ${ }^{1,2}$ Shahab Mahmoudvand, ${ }^{1,2}$ Manoochehr Makvandi, ${ }^{1,2}$ \\ Heshmatollah Shahbazian, ${ }^{3}$ Shokouh Shayanpur, ${ }^{4}$ Sepideh Nowrozi, ${ }^{5}$ Khojasteh Hoseini Nejad ${ }^{6}$ \\ ${ }^{1}$ Infectious and Tropical Disease Research Center; ${ }^{2}$ Department of Virology, School of Medicine; ${ }^{3}$ Research Institute \\ for Infectious Disease of Digestive System; ${ }^{4}$ Nephrology Department, Imam Khomeini Hospital; ${ }^{5}$ Golestan Hospital; \\ ${ }^{6}$ Ahvaz Jundishapur University of Medical Sciences, Ahvaz, Iran
}

\begin{abstract}
Hepatitis B virus is a major public health impasse all over the world. Recently a new form of hepatitis B infection named Occult hepatitis B Infection (OBI) has appeared globally. The OBI is defined as the presence of HBV DNA in the liver and/or blood in the absence of detectable serum HBsAg with/without anti-HBc or anti-HBs. The prevalence of OBI has been reported in hemodialysis (HD) patients in different regions of the world. Thus, this study investigated the prevalence of OBI among HD patients. The crosssectional study was carried out on $84 \mathrm{HD}$ patients. These sera were checked for HBsAg, HBc-IgG assessment using Enzyme linked immunosorbent assay. The DNA was extracted from the sera samples and tested for HBVDNA detection using Nested Polymerase
\end{abstract}

Correspondence: Manoochehr Makvandi, Infectious and Tropical Disease Research Center, Ahvaz Jundishapur University of Medical Sciences, Ahvaz, Iran.

Tel.: +98.916618168 - Fax: +98.6113738313 .

E-mail: manoochehrmakvandi29@yahoo.com

Key words: Occult hepatitis B virus; Hemodialysis; Enzyme linked immunosorbent assay; Nested Polymerase Chain Reaction.

Contributions: Manoochehr Makvandi designed the experiment and corrected the manuscript, Rahil Nahid Samiei performed the experiment, Somayeh Shokri and Shahab Mahmoudvand analyzed the data and wrote the manuscript, Heshmatollah Shahbazian contributed to developing the research design, Shokouh Shayanpur and Sepideh Nowrozi and khojasteh hoseini Nejad contributed to sample collection.

Conflict of interest: the authors declare no potential conflict of interest.

Funding: this study was financially supported by Ahvaz Jundishapur University of Medical Sciences (grant no: 92I05).

Received for publication: 22 April 2018.

Revision received: 6 July 2018.

Accepted for publication: 20 July 2018.

(C) Copyright R.N. Samiei et al., 2018

Licensee PAGEPress, Italy

Journal of Biological Research 2018; 91:7516

doi:10.4081/jbr.2018.7516

This article is distributed under the terms of the Creative Commons Attribution Noncommercial License (by-nc 4.0) which permits any noncommercial use, distribution, and reproduction in any medium, provided the original author(s) and source are credited.
Chain Reaction (Nested PCR). The liver function tests including serum alanine aminotransferase and aspartate aminotransferase levels were carried out for all the HD individuals. 52/84(61.9\%) of HD were males and 32/84 (38.1\%) were females. The patient's age ranged from 25 to 64 with a mean age of $52.4 \pm 15.2$ years. HBsAg and $\mathrm{HBc}-\mathrm{IgG}$ were detected in 1(1.1\%) female. 2 (2.4\%; a female and a male) patients were positive for HBsAg. 14/84 (16.7\%; 6 female and 8 male) HD patients were positive for anti-HBc but negative for HBsAg, among them 4(28.6\%; 2 female and 2 male) cases were positive for HBV DNA, indicating the presence of OBI in HD patients. Even distribution of $\mathrm{OBI}$ among the HD was found in $2(2.36 \%)$ male and $2(2.36 \%)$ female $(\mathrm{P}>.0 .05)$. In the present study the moderate rate of $4.76 \%$ OBI has been observed in HD patients. The prevalence of seropositive OBI among the gender was $2(2.36 \%)$ male and $2(2.36 \%)$ female. The seronegative OBI have not been detected in the present study but requires further investigation. In this study the affliction of OBI in HD patients is not clear.

\section{Introduction}

Hepatitis B is a serious and major public health problem despite the presence of an effective vaccine. ${ }^{1}$ The hepatitis B virus (HBV) is a well-known blood-borne virus because it is transmitted through exposure to infective blood, semen, and other body fluids, peripheral blood mononuclear cells (PBMCs) and sharing needles. ${ }^{2}$ Acute HBV can be a self-limiting or it can be chronic infection and increases the risk of developing liver failure, Hepatocellular carcinoma (HCC) or cirrhosis. ${ }^{3} \mathrm{HBV}$ infection is a major cause of chronic liver disease, affecting more than 240 million people worldwide. ${ }^{4}$ The diagnosis of acute HBV infection is based on presence of $\mathrm{HBsAg}$, anti-HBc and $\mathrm{HBeAg}$ in serum. HBV DNA is also detectable during acute and chronic infection. Chronic HBV infection is pinpointed by the presence of $\mathrm{HBs} \mathrm{Ag}$ in serum for at least six months. The meliorated carrier attitude is diagnosed by normal ALT levels, absence of HBe Ag, presence of anti-HBe and undetectable or low levels of HBV DNA $(<200 \mathrm{UI} / \mathrm{mL})$. Active carrier state is determined by high viral load $(\geq 20000 \mathrm{UI} / \mathrm{mL})$, whereas HBeAg could be present or absent with anti-HBe positivity. ${ }^{5}$ Occult hepatitis B infection (OBI) is a new clinical form of hepatitis $B$ that characterized as the presence of HBV DNA in the liver with detectable $(<200 \mathrm{UI} / \mathrm{mL})$ or undetectable HBV DNA in the serum in HBsAg negative patients and can be classified into seropositive (anti-HBc and/or anti-HBs positive) and seronegative (absence of anti- HBc and anti-HBs). ${ }^{6}$ It is estimated that about $20 \%$ of OBI infections are negative for all HBV serological markers but HBV DNA is detectable although the HBV viral load is may be often low. The seronegative OBI pattern is very important as a 
source of infection but it is very difficult to diagnose due to absence of serum HBV antigens or antibodies. ${ }^{7}$ In the diagnosis of OBI, the liver biopsy is needed. OBI is one of the most common causes of liver diseases in negative HBsAg patients. ${ }^{8}$ The prevalence of OBI varies from $1 \%$ to $87 \%$ in different regions of the world. The frequency of $\mathrm{OBI}$ in patients with liver cirrhosis and cryptogenic chronic liver ranged from $2.7 \%$ to $60 \%$ and $1.9 \%$ to $55.6 \%$ respectively. ${ }^{7}$

Patients with chronic renal failure (CRF) on hemodialysis are at higher risk for acquiring Hepatitis B Virus. ${ }^{9}$ HD patients, compared to patients without renal failure are more apt to become chronic HBV carriers. ${ }^{10}$ Using of common equipment for multiple blood transfusions, inadequate infection control methods, breaching of skin and the suppressed immunity of patients leads to a high prevalence of OBI rather than general population. ${ }^{11}$ The prevalence of OBI among hemodialysis patients and blood donors have been reported from $0 \%$ to $58 \%$ and 0 to $22.7 \%$ in different places of world. ${ }^{7}$ Thus, the important measure should be implemented to control of hepatitis in all dialysis departments.

Therefore, study was conducted to determine the prevalence of anti-HBc and HBV DNA in the HD patients with undetectable HBs $\mathrm{Ag}$ in Ahvaz city. Ahvaz is the capital of Khozestan province with about 2 million population, located at south west region of Iran.

\section{Materials and Methods}

\section{Patients}

The study subjects comprised 84 patients undergoing hemodialysis at Golestan hospital in Ahvaz during October 2014 and November 2014. Serum samples were collected, aliquoted, and then stored at $-80^{\circ} \mathrm{C}$ until further analyses.

\section{Enzyme-linked immuno assay test}

The presence of anti-HBc and HBs Ag were determined by Enzyme-Linked Immuno Assay test kit (Diapro, Milano, Italy) according to the manufacturer's instruction. Patients who were positive for total anti-HBc and negative for $\mathrm{HBs} \mathrm{Ag}$ were investigated for HBV DNA.

\section{DNA extraction}

DNA was extracted from specimens using High Pure Viral Nucleic Acid Kit (Roche, Germany) according to manufacturer's instructions. The extracted DNA was stored at $-20^{\circ} \mathrm{C}$ till used.

\section{Nested polymerase chain reaction}

The following primers were used for detection of HBV DNA:

Outer primers, PC16: 5'-GTTGCATGGAGACCACCGTGAAC-3'(nt.1605-1627) and PC17:5' CTTCTGCGACGCGGCGATGGAGA-3' (nt. 2410-2432);

Inner primers, PC70: 5-'CATAAGAGGACTCTTGGACT3'(nt.1655-1674)and PC74:5' GGCGAGGGAGTTCTTCTTC-3' (nt. 2378 - 2396). ${ }^{12}$

First round PCR was performed with $25 \mu$ l volume, containing $7 \mu 1$ of HBV DNA as template, $2.5 \mu 110 \mathrm{x}$ reaction buffer, $0.75 \mu 1$ $\mathrm{MgCl}_{2}(50 \mathrm{mM}), 0.5 \mu \mathrm{l}$ forward/reverse primer, $1 \mu \mathrm{L}$ dNTP (10 $\mathrm{mM}), 0.2$ Cinna Gen Taq DNA Polymerase $(5 \mathrm{u} / \mu \mathrm{l})$, and $13.55 \mu \mathrm{l}$ double-distilled water. The reaction mixture was subjected to thermal cycler (TC-512, Techne, Staffordshire, UK) with the following program: 1 cycle with initial denaturation at $94^{\circ} \mathrm{C}$ for 5 minutes, followed by 35 cycles, $94^{\circ} \mathrm{C}$ for 1 minute, $60^{\circ} \mathrm{C}$ for 1 minute, $72^{\circ} \mathrm{C}$ for 2 minutes, and final extension at $72^{\circ} \mathrm{C}$ for 10 minutes. The first round of PCR product was used as the template for the second round. The amount of PCR components was the same as the first round except for the DNA template, which $5 \mu$ l was used in the second round. The thermal cycler was programmed as follows: initial denaturation at $94^{\circ} \mathrm{C}$ for 5 minutes, 30 cycles consisting of $94^{\circ} \mathrm{C}$ for 1 minute, $44^{\circ} \mathrm{C}$ for 1 minute, $72^{\circ} \mathrm{C}$ for 1.5 minutes, and final extension at $72^{\circ} \mathrm{C}$ for 10 minutes. All reactions were performed in the presence of negative and positive controls. The positive control was kindly provided by Ahvaz Blood Transfusion Center.

The $730 \mathrm{bp}$ PCR product was subjected to electrophoresis on a $1 \%$ agarose gel supplemented with DNA safe Stain (Cinna Gen) and visualized using a UV trans illuminator (Kiagen, Tehran, Iran).

The positive PCR products were sent to Bioneer Company (Korea) and sequenced in one direction. The results of sequencing were blasted to determine homology identification and HBV genotyping using the online nucleotide BLAST [National Center for Biotechnology Information (NCBI)] (http://www.ncbi.nlm.nih. gov/BLAST/).

\section{Ethic consent}

All of the subjects included in the study were orally informed about the purpose of the study and invited to participate. Each patient gave informed consent. The research was conducted in accordance with the Declaration of Helsinki (as revised in 2008) and according to local guidelines and laws. The project was approved by ethic committee of Ahvaz Jundishapur university of Medical Sciences, Ahvaz Iran. At baseline, all study participants were requested to complete a questionnaire to obtain demographic lifestyle, socio-economic, and clinical data in order to assess their previous exposure to viral hepatitis. These patients have undergone dialysis for many times and to maintain patients' confidentiality, the number is unknown.

\section{Statistical analysis}

Data analysis was performed using the Statistical Package for the Social Sciences 16.0 (SPSS Inc., Chicago, IL, USA). Chi-Square test was used to calculate. $\mathrm{P}<0.05$ was accepted as significant.

\section{Results}

From the total of 84 patients, $52(61.9 \%)$ were males with a mean age of 51 years and $32(38.1 \%)$ were females with a mean age of 53 years. The ages ranged from 18 to 85 years (with a mean of $52.4 \pm 1.57$ years). The demographic results of the hemodialysis population are shown in Figure 1. Characteristics of study population are provided in Table 1. Levels of AST enzymes was higher in patients with occult HBV infection when compared to those patients without occult HBV (Table 2), but the differences did not reach statistical significance. The results of all sequenced PCR products revealed that they were homology identity to HBV genotype D. No statistically significant difference was observed between OBI seroprevalence and gender $(\mathrm{P}=0.76)$.

\section{Discussion and Conclusions}

Despite effective vaccine against HBV infection, HBV-related acute and chronic liver disease is one of the leading causes of death. ${ }^{13}$ Hepatitis B surface antigen assay is most frequently used to analyze the presence of $\mathrm{HBV}$ infection. The screening of $\mathrm{HBsAg}$ 
test is implemented for further strategy program to prevent spread of HBV infectious diseases. HBs Ag variants arise as an escape mechanism during infection. Therefore, diagnostic of HBV infection might be overlooked with measurement of HBs Ag only. ${ }^{14}$

The application of molecular techniques including PCR and real time PCR are important means to analyze the status of OBI. Finding the real prevalence of OBI may not be quite feasible because detection of HBV DNA in liver biopsy is a valuable diagnostic tool in patients who serological tests negative for $\mathrm{HBs} \mathrm{Ag}$ and anti-HBc, but this is not possible because it has many drawbacks, such as sampling error, cost, and risk of complications. Therefore the diagnosis of OBI is mostly based on the analysis of serological with molecular assays. ${ }^{15,16}$

In this study, all HD patients had a history of blood transfusion and the prevalence of OBI infection was determined as 4/84 $(4.76 \%)$ in HD patients who were negative for HBs Ag but positive for anti-HBc and HBV DNA. In Iran, different rates of OBI have been reported among the HD patients.

Ayatollahi et al. have found anti-HBc in 3/126 (2.4\%) HD patients which among them HBV DNA detection was $1 / 3(33.3 \%)$ cases. ${ }^{17}$ Aghakhani et al. reported 6.2\% (18/289) anti-HBc and the HBV DNA detection in 9/18 (50\%) HD patients. ${ }^{18}$ In Kalantari et al study $32 / 400(8 \%)$ patients were positive for anti-HBc and all of them $(0 \%)$ were negative for HBV DNA. ${ }^{19}$ Neisi et al. have described that $4 \%$ of HD patients were positive for HBVDNA by PCR test but negative for HBsAg test. ${ }^{20}$ Rastegarvand et al. have declared 6/203(2.9\%) HD patients were positive for HBV DNA, but negative for HBsAg test. ${ }^{21}$ Ramezani et al. demonstrated 2/100(2\%) of $\mathrm{HD}$ patients were positive for anti-HBc test, negative for $\mathrm{HBsAg}$ test, among them HBV DNA was detected in $1(1 \%)$ case. $^{22}$

The spread of OBI is relied on endemicity of HBV infection, inadequate management of dialysis unit, familial HBV infection and contaminated blood transfusion. Since, the prevalence of HBV infection in Iran is intermediate, the rate of OBI proportionally is low to moderate in different regions of Iran. ${ }^{23}$

The detection of anti-HBc has been demonstrated in $80 \%$ of seropositive OBI individual, Thus the use of anti-HBc test is a good tract for detection of seropositive OBI. ${ }^{24,25}$ In developed countries, the NAT (Nucleic Acid Test) is used for screening of HBV DNA in blood donors while in the most under developing countries, the application of NAT (Nucleic Acid Test) is very costly. ${ }^{7}$ Ultimately, the screening of anti-HBc is a good means to prevention and control of OBI specially in blood donors, With the aforementioned data, to prevention and control of OBI the screening of anti-HBc should be implemented for all blood donors.

Generally the activities of specific CD4 and CD8 in infected individuals with HBV infection lead to raising the AST and ALT levels while in HD patients with infection, the activities of specific viral immune system including CD4 and CD8 lymphocytes will remain dysfunction and declined, thus the level of AST and ALT will not be elevated. ${ }^{26,27}$ In this regard it has been hypothesized that status of chronic uremia in HD patients may suppress the

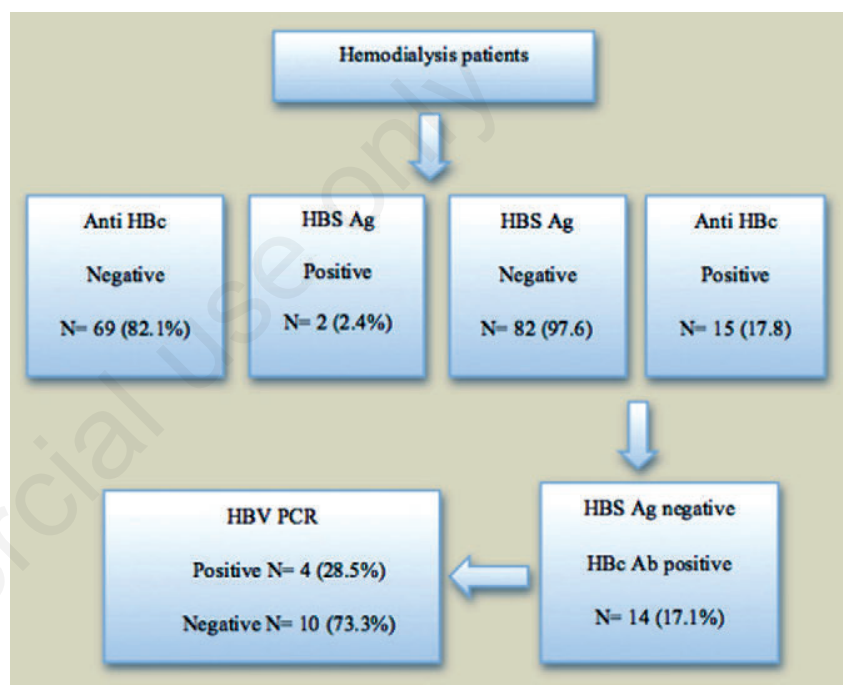

Figure 1. The demographic results of the hemodialysis population.

Table 1. Frequency based on gender and age.

\begin{tabular}{|c|c|c|c|c|c|c|}
\hline Parame & & HBs Ag (+) & Anti-HBc(+) & $\begin{array}{c}\text { HBs Ag (+) } \\
\text { anti-HBc (+) }\end{array}$ & $\begin{array}{c}\text { HBS Ag (-) } \\
\text { anti-HBc (+) }\end{array}$ & HBVDNA (+) \\
\hline \multirow[t]{2}{*}{ Gender } & Male $\mathrm{N}=52$ & $\mathrm{~N}=11.9 \%$ & $\mathrm{~N}=815.4 \%$ & 0 & $\mathrm{~N}=857.1 \%$ & $\mathrm{~N}=23.8 \%$ \\
\hline & Female $\mathrm{N}=32$ & $\mathrm{~N}=13.1 \%$ & $\mathrm{~N}=721.9 \%$ & $\mathrm{~N}=1100 \%$ & $\mathrm{~N}=642.9 \%$ & $\mathrm{~N}=26.3 \%$ \\
\hline
\end{tabular}

$\mathrm{HB}$, hepatitis B.

Table 2. Relationship between hepatitis B virus (HBV) serologic tests and liver biochemistry tests.

\begin{tabular}{lcc} 
Patients & ALT ( $\mathbf{0}-\mathbf{4 0}$ IU/L)Mean & AST (0-33 IU/L)Mean \\
HBs Ag positive $(\mathrm{N}=2)$ & $8.0 \pm 4.2$ & $23.0 \pm 2.8$ \\
Anti-HBc positive $(\mathrm{N}=15)$ & $8.7 \pm 3.8$ & $32.4 \pm 17.7$ \\
\hline HBs Ag positive, anti-HBc positive (N=1) & 5.0 & 25.0 \\
HBs Ag negative, anti-HBc negative (N=68) & $12.01 \pm 10.2$ & $31.7 \pm 18.9$ \\
\hline HBs Ag negative, Anti-HBc positive (N=14) & $9.0 \pm 3.9$ & $32.9 \pm 18.2$ \\
HBV DNA positive $(\mathrm{N}=4)$ & $7.5 \pm 1.5$ & $38.2 \pm 35.6$ \\
\hline HBV DNA negative $(\mathrm{N}=10)$ & $11.61 \pm 9.6$ & $31.4 \pm 17.6$ \\
\hline
\end{tabular}

ALT, alanine aminotransferase; AST, aspartate aminotransferase. 
inflammatory reactions in the liver and consequently no hepatocyte destruction will occur. Thus the evaluation of HBV DNA detection was found to be the most efficient method to evaluate OBI in HD patients. ${ }^{7}$ In this way, in the present study the levels of AST and ALT were remained normal in the patients with OBI. Our findings consistent of the study performed by Alavian et al. ${ }^{28}$

Reactivation of OBI has been observed in other conditions that cause immunosuppression, in which antiviral therapy could be delayed until the HBV DNA or HBsAg becomes detectable. ${ }^{29}$ For those with OBI, especially in the absence of anti-HBs, a prudent therapeutic approach is to initiate HBV antiviral therapy (lamivudine, telbivudine, adefovir, entecavir or tenofovir) prior to chemotherapy. This should be continued for $\geq 6$ mo after stopping immunosuppressive treatment. If long-term treatment $(>12 \mathrm{mo})$ is predicted, then adefovir, entecavir or tenofovir should be chosen, and if a more rapid response is needed, then entecavir or tenofovir could be considered. Antiviral therapy is usually unsuccessful if started after alanine aminotransferase becomes elevated. ${ }^{24}$

To prevent spreading of OBI, the screening of anti-HBc followed by HBV DNA should be implemented for all HD patients. The vaccination of HBV should be implemented for HD patients negative for HBsAg. In addition to, the screening of anti-HBc should be done in blood donors and blood donors with positive anti-HBc antibody should be omitted from the blood donation.

In conclusion, HD patients require frequent blood transfusions: they are at a high risk of acquiring HBV and OBI infections. The HD patients with OBI infection remain as a silent disease which may result in severe complications. Hence to control HBV infection, periodically the screening of HBV DNA in HD patients should be implemented by molecular tools such as Nested PCR or Real time PCR.

The current experiment did not investigate the seronegative OBI whereas further study of the issue would be of interest. In this study, the affliction of OBI in HD patients is not clear.

\section{References}

1. Salvatierra K, Florez H. Prevalence of hepatitis band c infections in hemodialysis patients. F1000Res 2016;5:1-7.

2. Hornor G. Sexually transmitted infections and children: what the PNP should know. J Pediatr Health Care 2017;31:222-9.

3. Sundaram V, Kowdley K. Management of chronic hepatitis b infection. Br Med J 2015;1-12.

4. Rosa AS, Araujo OC, Savassi-Ribas F, et al. Prevalence of occult hepatitis $b$ virus infection and torque teno virus infection and their association with hepatocellular carcinoma in chronic hepatitis c patients. Virus Res 2017;242:166-72.

5. Bozza C, Cinausero M, Iacono D, Puglisi F. Hepatitis b and cancer: a practical guide for the oncologist. Crit Rev Oncol Hematol 2016;98:137-46.

6. Saha D, Pal A, Sarkar N, et al. Occult hepatitis b virus infection in HIV positive patients at a tertiary healthcare unit in eastern India. PloS One 2017;12:1-18.

7. Makvandi M. Update on occult hepatitis b virus infection. World J Gastroenterol 2016;22:8720-34.

8. Nishikawa H, Osaki Y. Clinical significance of occult hepatitis $\mathrm{b}$ infection in progression of liver disease and carcinogenesis. J Cancer 2013;4:473-80.

9. Otedo AE, Mc'Ligeyo SO, Okoth FA, Kayima JK. Seroprevalence of hepatitis $\mathrm{b}$ and $\mathrm{c}$ in maintenance dialysis in a public hospital in a developing country. S Afr Med J 2003;93:380-4.
10. Al Hijazat M, Ajlouni Y. Hepatitis b infection among patients receiving chronic hemodialysis at the royal medical services in Jordan. Saudi J Kidney Dis Transpl 2008;19:260-7.

11. Coppola N, Tonziello G, Pisaturo M, et al. Reactivation of overt and occult hepatitis b infection in various immunosuppressive settings. J Med Virol 2011;83:1909-16.

12. Kumar GT, Kazim SN, Kumar M, et al. Hepatitis b virus genotypes and hepatitis b surface antigen mutations in family contacts of hepatitis b virus infected patients with occult hepatitis b virus infection. J Gastroenterol Hepatol 2009;24:588-98.

13. Esmat MM, Mohamed T, Zazi NAE. Occult Hepatitis b virus infection among Egyptian hepatitis c virus seropositive and seronegative hemodialysis patients in Sohag government, upper Egypt. Egypt J Med Microbiol 2015;24:113-8.

14. Saijo T, Joki N, Inishi Y, et al. Occult hepatitis b virus infection in hemodialysis patients in Japan. Ther Apher Dial 2015;19:125-30.

15. Levast M, Larrat S, Thelu MA, et al. Prevalence and impact of occult hepatitis b infection in chronic hepatitis c patients treated with pegylated interferon and ribavirin. J Med Virol 2010;82:747-54.

16. Sumida Y, Nakajima A, Itoh Y. Limitations of liver biopsy and non-invasive diagnostic tests for the diagnosis of nonalcoholic fatty liver disease/nonalcoholic steatohepatitis. World J Gastroenterol 2014;20:475-85.

17. Ayatollahi J, Jahanabadi S, Sharifyazdi M, et al. The Prevalence of occult Hepatitis b virus in the hemodialysis patients in Yazd, Iran. Acta Med Iran 2017;54:784-7.

18. Aghakhani A, Banifazl M, Kalantar E, et al. Occult hepatitis b virus infection in hemodialysis patients with isolated hepatitis b core antibody: a multicenter study. Ther Apher Dial 2010;14:349-53.

19. Kalantari H, Ferdowsi F, Yaran M. Prevalence of occult hepatitis $b$ virus infection in hemodialysis patients in Isfahan, Iran. Adv Biomed Res 2016;5:151.

20. Neisi N, Makvandi M, Ali Samarbaf-Zadeh R. A study on genotypes of hepatitis $\mathrm{b}$ virus among hemodialysis patients in Khuzestan province. Jundishapur J Microbiol 2011;4:65-70.

21. Rastegarvand N, Makvandi M, Samarbafzadeh A, et al. Molecular characterization of pre-core/core and s region of hepatitis $b$ virus in hemodialysis patients with occult hepatitis b infection. Jundishapur J Microbiol 2015;8:1-5.

22. Ramezani A, Aghasadeghi MR, Ahmadi F, et al. Isolated anti$\mathrm{HBc}$ and occult HBV infection in dialysis patients. Nephrourol Mon 2015;7:1-5.

23. Azizolahi B, Rajaei E, Taherkhani R, Makvandi M. Low detection of hepatitis $b$ and occult hepatitis $b$ infection in patients with rheumatic diseases. Egypt Rheumatol 2017;39:239-43.

24. Hollinger F, Sood G. Occult hepatitis b virus infection: a covert operation. J Viral Hepat 2010;17:1-15.

25. Meidani M, Rostami M, Hemmati S, et al. Screening and evaluation of chronic and occult Hepatitis b in chemo-radiotherapy patients with cancer. Adv Biomed Res 2016;5.

26. Kwo PY, Cohen SM, Lim JK. ACG clinical guideline: evaluation of abnormal liver chemistries. Am J Gastroenterol 2017;112:8-35.

27. Yakaryilmaz F, Alp Gurbuz O, Guliter S, et al. Prevalence of occult hepatitis $\mathrm{b}$ and hepatitis $\mathrm{c}$ virus infections in Turkish hemodialysis patients. Ren Fail 2006;28:729-35.

28. Alavian SM. Occult hepatitis b virus infection among hemodialysis patients. Hepat Mon 2012;12:242-3.

29. Baker RJ, Mark PB, Patel RK, et al. Renal association clinical practice guideline in post-operative care in the kidney transplant recipient. BMC Nephrol 2017;18:1-41. 